7. Тюрменко I. Цифрова історико-культурна спадщина на веб-сайтах архівних установ України та Франції: порівняльний аналіз. - Режим доступу: http://ena.lp.edu.ua:8080/bitstream/ntb/25024/1/134-282-283.pdf. — Назва з екрана.

8. Лобузін I. B. Технології інтеграції міжнародних та національних бібліотечних цифрових ресурсів / I. В. Лобузін // Бібліотекознавство. Документознавство. Інформологія. — Київ, 2017. — № 1. - С. 66-78.

9. Коновал Л. Функціонування національних цифрових бібліотечних проєктів у контексті формування електронної бібліотеки "Україніка" / Л. Коновал // Бібліотечний вісник. — 2016. — № 2. — С. 11—16.

\title{
Natalia Loshchinskaya Popular online libraries with Ukrainian content
}

New historical stage of development of society in the XXI century determines the need for transformation of scientific and practical activity of modern scientific libraries, improvement and development of certain provisions of library science, harmonization of library theory and practice with the basic requirements of the modern online community. The outlined problems should be facilitated by the Law of Ukraine "On the National Program of Informatization" (№ 74/98-BP of February 4, 1998), which regulates the processes of providing citizens and society with timely, reliable and complete information through the widespread use of Internet technologies. The place, role and prospects of functioning in the information space of electronic libraries with Ukrainianlanguage content are investigated in the article. The ten most popular modern libraries are reviewed by their structure, tasks, content and content, openness of information and more. A brief overview of the works of Ukrainian researchers and the UNESCO-approved European Digital Heritage Charter is presented.

The issue of creating online libraries is topical, and therefore, in the information and library environment, various aspects of their activity are being actively studied. First of all, it is important to pay attention to the connection of electronic libraries with the educational needs of high and high school students. Today, virtual library resources are one of the most productive areas for digital technology development, and we can confidently predict their intense development in the near future.

Keywords: online library; digitization; content; digital document; website; digitized resources; digital media; media files

\section{References}

1. Bondarenko V. (2015). Elektronni biblioteky v konteksti dyskantnoho obsluhovuvannia korystuvachiv. Visnyk Knyzhkovoi palaty, 6 , pp. $141-156$.

2. Pavlusha I. A. (2002). Stvorennia ta rozvytok elektronnykh bibliotek v Ukraini: bibliotekoznavchyi aspekt (kinets XX pochatok XXI st. PhD dissertation (History). V. Vernadsky National Library of Ukraine, Kyiv.

3. Reznichenko V. A. (2005). Elektronni biblioteky: informatsiini resursy ta servisy. Problemy prohramuvannia, 4, pp. 60-72.

4. Lobuzina K. V. (2001). Linhvistychne zabezpechennia elektronnykh bibliotek. Reiestratsiia, zberihannia i obrobka danykh. Vol. 3 (3), pp. $78-87$.

5. Pasmor N. P. (2019). Elektronni biblioteky yak element informatsiinoho suspilstva. Available at: http:// dspace.nlu.edu.ua/bitstream /123456789/5526/1/Pasmor.pdf.

6. Onyshchenko O. S. (2013). Tendentsiyi vplyvu hlobalnoho informatsiynoho seredovyshcha na sotsiokulturnu sferu Ukrayiny. Kyiv.

7. Tyurmenko I. (2020). Tsyfrova istoryko-kulturna spadshchyna na veb-saytakh arkhivnykh ustanov Ukrayiny ta Frantsiyi: porivnyalnyy analiz. Available at: http://ena.lp.edu.ua:8080/bitstream/ntb/25024/1/134-282-283.pdf.

8. Lobuzin I. V. (2017). Tekhnolohiyi intehratsiyi mizhnarodnykh ta natsionalnykh bibliotechnykh tsyfrovykh resursiv. Bibliotekoznavstvo. Dokumentoznavstvo. Informolohiya, 1, pp. 66-78.

9. Konoval L. (2016). Funktsionuvannya natsionalnykh tsyfrovykh bibliotechnykh proektiv u konteksti formuvannya elektronnoyi biblioteky "Ukrayinika". Bibliotechniy visnyk, 2, pp. 11-16.

Надійшла до редакції 21 січня 2020 року

\section{ІНФОРМАЦИЙНА ДІЯЛЬНІСТЬ}

УДК 025.321:004'24](045)

DOI: 10.36273/2076-9555.2020.2(282).33-37

Олександр Кузнсцов,
завідувач відділу наукового комплектування
та опрацювання фондів ДНТБ Украйни,
e-mail: kuznetsov021@gmail.com,
ORCID: https://orcid.org/0000-0002-9902-1295

Автоматизація створення бібліографічного опису авторефератів

У статті розглянуто аспекти оптимізачії процесу каталогізаиії авторефератів дисертаиій у Державній науковотехнічній бібліотечі (ДНТБ) України. Автоматизачія введення бібліографічних описів авторефератів дисертачій у базу даних трунтується на тому, що згідно з чинними правилами бібліографічний опис видання здійснюють із титульного аркуша. Однак автореферати не мають титульного аркуша, тому каталогізатори опрацьовують основні відомості, уміщені на обкладинці. Відповідно до правил складання автореферату дисертачї титульний аркуш оформлено так, щяо кожний абзач містить певну бібліографічну інформачію.

Прочес автоматизачії створення бібліографічного опису авторефератів фактично передбачає програмне розставлення індексів розділення в тексті з обкладинок цих документів, що спрощує їх подальший імпорт у відповідну базу даних. 
Проаналізований прочес автоматизованого введення авторефератів у базу даних розроблено за допомогою програмного забезпечення VВА для Word та апробовано у відділі наукового комплектування і опрачювання фондів ДНТБ.

Ключові слова: каталогізачія; автореферати; автоматизачія; бібліографічний опис; алгоритм; кодування

Постановка проблеми. Державна науково-технічна бібліотека України від 1992 р. здійснює формування фонду вітчизняних авторефератів дисертацій (далі - авторефератів). Від 2006 р. каталогізація відбувається в електронному каталозі САБ ІРБІС (далі - ЕК).

Динаміку надходження авторефератів до фонду бібліотеки за останні п'ять років подано на діагр. 1. Відомості наведено з бази даних "Книги та періодика" ДНТБ України за 2015-2019 рр. (станом на 23.10.2019), що містить і бібліографічні записи авторефератів.

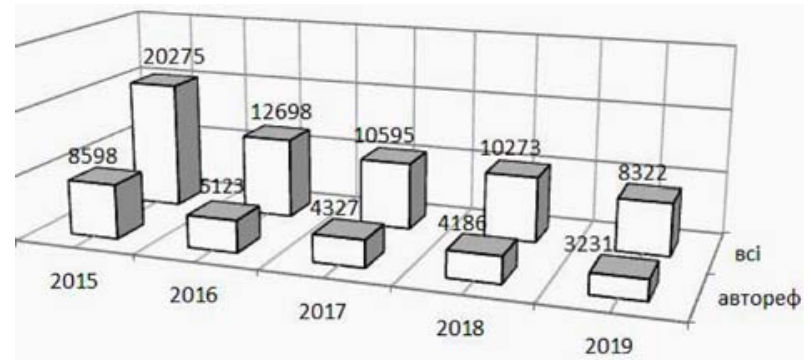

Діагр. 1. Динаміка надходження авторефератів

Згідно з наведеними показниками, надходження авторефератів від 2016 р. стабілізувалося й становило в середньому 4200 примірників на рік. Під час введення бібліографічних описів авторефератів до ЕК ДНТБ України каталогізатор заповнює понад 40 полів, що потребує значних витрат часу, тому вдосконалення цих процесів є актуальним завданням.

Мета статті - проаналізувати особливості автоматизації створення бібліографічного опису авторефератів, що дасть змогу заощадити час і оптимізувати працю каталогізаторів.

Виклад основного матеріалу дослідження. Автореферат оформлюють відповідно до національних стандартів: ДСТУ 3008:2015 "Інформація та документація. Звіти у сфері науки і техніки. Структура та правила оформлювання"; ДСТУ 7.1:2006 "Система стандартів 3 інформації, бібліотечної та видавничої справи. Бібліографічний запис, бібліографічний опис. Загальні вимоги та правила складання", а також Вимог до оформлення дисертацій та авторефератів дисертацій [1].
Бібліографічний опис видання створюють із титульного аркуша, однак автореферати його не мають, тому каталогізатори опрацьовують основні відомості, уміщені на обкладинці. Стандартизовані вимоги щодо оформлення авторефератів дають змогу здобути потрібні відомості, адже в кожному рядку розміщено інформацію для введення у відповідне поле бази даних.

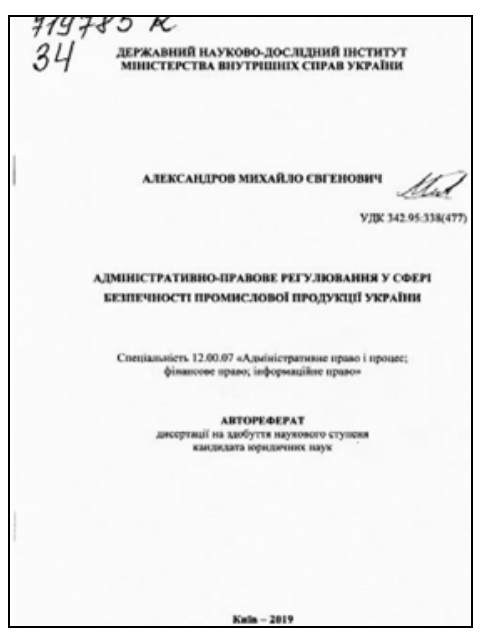

Рис. 1. Приклад оформлення обкладинки автореферату

Для оптимізації процесу каталогізації автореферату (рис. 1) слід зісканувати його обкладинку, після чого розпізнати файл у текстовому форматі за допомогою Fine Reader 9 (чи пізнішої версіï), Word 2016 (розпізнає файли pdf без текстового шару), онлайнсервісів, Гугл-диску. Відтак каталогізатор здобуває текстові дані (табл. 1).

Для повноти бібліографічного запису потрібно заповнити певні службові поля. Для авторефератів вони відомі: \#101: ukr, \#102: UA, \#900: ^Cm1, \#920: PAZK, \#907: ${ }^{\wedge} \mathrm{CKT}^{\wedge} \mathrm{A} 20190916^{\wedge}$ Bsns, \#919: ${ }^{\wedge} \mathrm{Aukr}$, \#905: ${ }^{\wedge} \mathrm{B} 1^{\wedge} \mathrm{F} 1^{\wedge} \mathrm{H} 1^{\wedge} \mathrm{J} 1 \wedge 21, * * * * *$.

Розпізнаний текст у Word слід виділити та опрацювати за допомогою макросу VBA. Розглянемо як найцікавіший фрагмент другий абзац - АЛЕКСАНДРОВ МИХАЙЛО СВГЕНОВИЧ. Для ЕК це поле 700. Алгоритм опрацювання наведено в табл. 2.

Табличя 1

Текстові дані з обкладинки автореферату

\begin{tabular}{|c|c|c|}
\hline № абз. & Зміст & Коди ЕК \\
\hline 1 & МІНІСТЕРСТВО ВНУТРІШНІХ СПРАВ УКРАЇНИ & $\# 200^{\wedge} \mathrm{G}$ \\
\hline 2 & ДЕРЖАВНИЙ НАУКОВО-ДОСЛІДНИЙ ІНСТИТУТ & \#710: ${ }^{\wedge} \mathrm{A}$ \\
\hline 3 & АЛЕКСАНДРОВ МИХАЙЛО СВГЕНОВИЧ & \#700: ^ААлександров^ВM.Є.^ ${ }^{\wedge}$ GMихайло Свгенович \\
\hline 4 & УДК $342.95: 338(477)$ & \#675: \\
\hline 5 & $\begin{array}{l}\text { АДМІНІСТРАТИВНО-ПРАВОВЕ РЕГУЛЮВАННЯ У СФЕРІ } \\
\text { БЕЗПЕЧНОСТІ ПРОМИСЛОВОЇ ПРОДУКЦІЇ УКРАЇНИ }\end{array}$ & $\# 200: \wedge A$ \\
\hline 6 & $\begin{array}{l}\text { Спеціальність } 12.00 .07 \text { "Адміністративне право і процес; } \\
\text { фінансове право; інформаційне право" }\end{array}$ & $\# 328:{ }^{\wedge} \mathrm{N} 12.00 .07$ \\
\hline 7 & АВТОРЕФЕРАТ дисертації на здобуття наукового ступеня & У поля для додаткової інформації \\
\hline 8 & кандидата юридичних наук & \#328: ^Акандидата юридичних наук \\
\hline 9 & Київ - 2019 & \#210: ^D2019^АКиїв \\
\hline
\end{tabular}


Алгоритм опрацювання абзаців

\begin{tabular}{|l|l|l|}
\hline № & \multicolumn{1}{|c|}{ Зміст операції } & \multicolumn{1}{|c|}{ Результат } \\
\hline 1 & Взяти потрібний абзац & АЛЕКСАНДРОВ МИХАЙЛО СВГЕНОВИЧ \\
\hline 2 & Зробити всі літери маленькими & александров михайло євгенович \\
\hline 3 & Зробити кожне слово з великої літери & Александров Михайло Свгенович \\
\hline 4 & $\begin{array}{l}\text { Зробити ініціали з другого та третього слова } \\
\text { (понад два символи між пробілами) }\end{array}$ & М. Є. \\
\hline 5 & Розставити коди & \#700: ^ААлександров ${ }^{\wedge}$ ВМ.С.`GМихайло Свгенович \\
\hline
\end{tabular}

Далі потрібно виділити розпізнаний текст із титульної сторінки, натиснути Alt+F8, вибрати потрібний макрос - і запис готовий (рис. 2).

У результаті виконання наведених операцій сформовано запис для ЕК (рис. 3).

Надалі каталогізатор дотримується цього алгоритму, опрацьовуючи потрібну кількість титульних сторінок авторефератів. Записи слід зберігати в текстовому файлі 3 будь-яким ім'ям і розширенням "txt". Кожен запис закінчується позначкою ***** (на нашу думку, це вдалий вибір розробників ЕК для розділення записів). Далі застосовують "Сервіс-Імпорт" i формат даних - текстовий у модулі "Каталогізатор".
Вибір кодування під час імпорту записів залежить від кодування тексту. Доцільно використовувати редактор "Блокнот", наявний у системах Windows. Всі записи слід скопіювати 3 Word i вставити в редактор "Блокнот", а потім імпортувати (рис. 4).

Зрозуміло, що зберігання файлу та імпорт записів у базу даних мають відбуватися за умови однакового кодування, інакше не уникнути спотворення символів ("кракозябрів"). Результат наведено на рис. 5.

Аналіз економії дій під час введення запису наведено в табл. 3.

Отже, економія кількості кліків сягає понад три сотні, а це непоганий результат для одного запису!

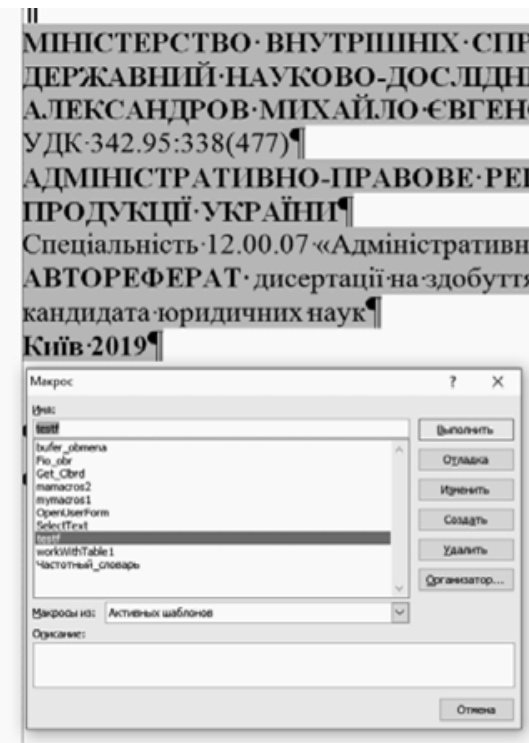

Рис. 2. Запуск макросу

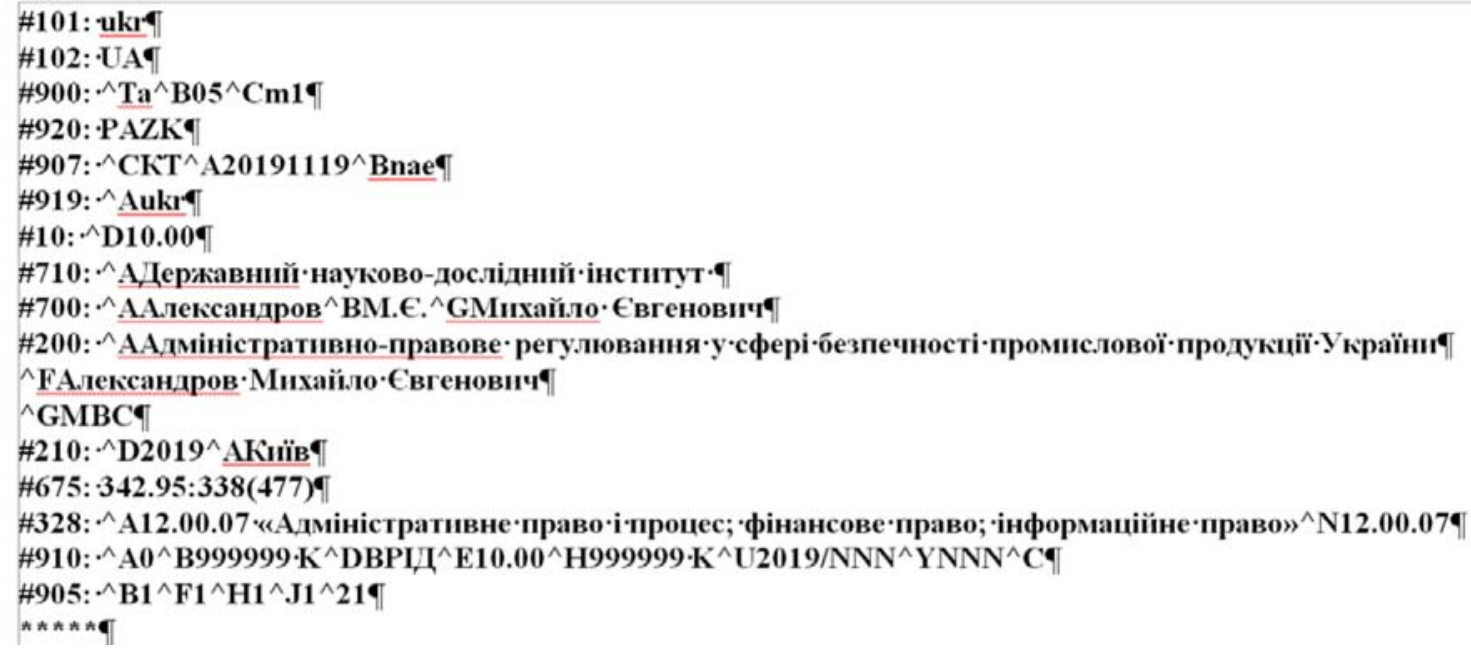

Рис. 3. Результат дї макросу: заміна виділеного фрагменту текстом запису 
ISSN 2076-9326. Вісник Книжкової палати. 2020. № 2
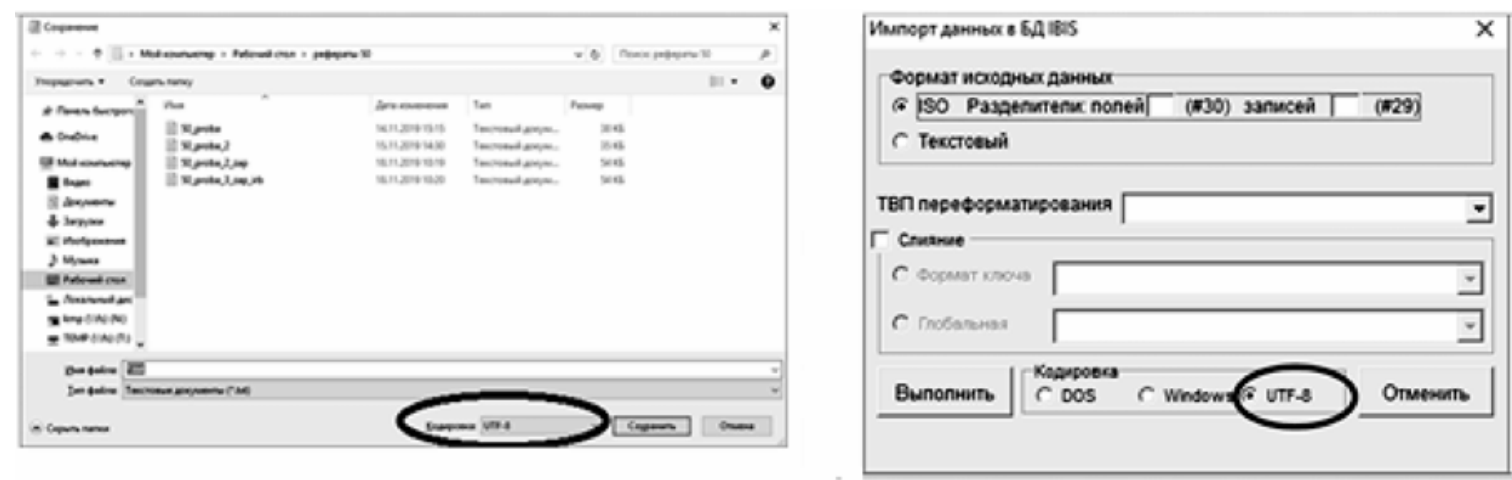

Pис. 4. Зберігання файлу та імпорт записів

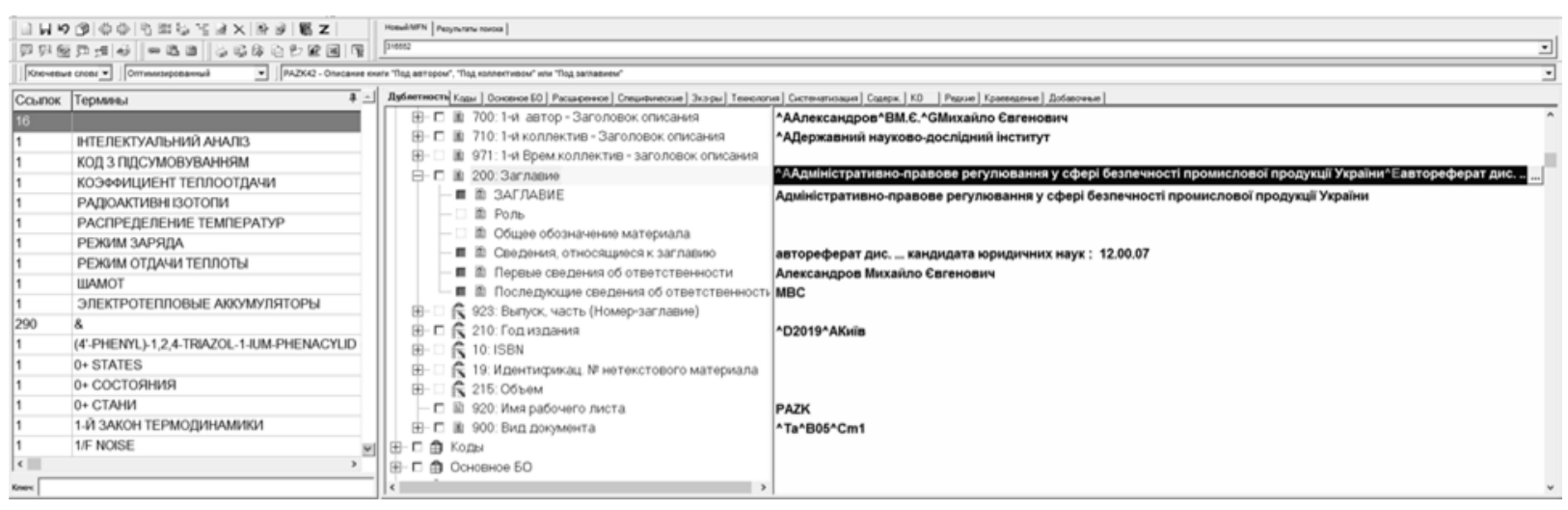

Рис. 5. Результат імпорту запису

Табличя 3

Аналіз економії дій

\begin{tabular}{|c|c|c|c|}
\hline № поля & Назва поля & $\begin{array}{c}\text { Кількість кліків } \\
\text { чи натискань } \\
\text { клавіатури } \\
\end{array}$ & Примітки \\
\hline \#101: ukr & Мова & 1 & Вибір з меню \\
\hline \#102: UA & Країна & 1 & Вибір з меню \\
\hline $\begin{array}{l}\# 900: \\
\wedge \mathrm{Ta} \\
\stackrel{\wedge}{ } \mathrm{B} 05 \\
{ }^{\wedge} \mathrm{Cm} 1\end{array}$ & $\begin{array}{l}\text { Коди: } \\
\text { тип } \\
\text { вид } \\
\text { характер }\end{array}$ & 3 & Вибір з меню \\
\hline \#920: PAZK & Назва робочого листа & 0 & Автоматично \\
\hline \#907: ^CKT`A20191119^Bnae & $\begin{array}{l}\text { Етап роботи, дата, } \\
\text { каталогізатор }\end{array}$ & 0 & Автоматично \\
\hline \#919: ^Aukr & Мова документа & 1 & Вибір з меню \\
\hline$\# 10:^{\wedge} \mathrm{D} 10.00$ & Ціна & 5 & Набір на клавіатурі \\
\hline \#710: ^АДержавний науково-дослідний інститут & Колективний автор & 36 & Набір на клавіатурі \\
\hline 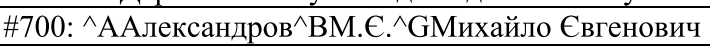 & Перший автор ПІБ & 31 & Набір на клавіатурі \\
\hline $\begin{array}{l}\text { \#200: ^ААдміністративно-правове регулювання } \\
\text { у сфері безпечності промислової продукції України }\end{array}$ & Назва & 86 & Набір на клавіатурі \\
\hline ^FАлександров Михайло Євгенович & $\begin{array}{l}\text { Перші відомості } \\
\text { про відповідальність }\end{array}$ & 31 & Набір на клавіатурі \\
\hline${ }^{\wedge} \mathrm{GMBC}$ & $\begin{array}{l}\text { Наступні відомості } \\
\text { про відповідальність }\end{array}$ & 3 & $\begin{array}{l}\text { Набір на клавіатурі, } \\
\text { скорочення } \\
\text { за таблицею }\end{array}$ \\
\hline \#210: ^D2019^АКиїв & Рік видання & 8 & Набір на клавіатурі \\
\hline$\# 675: 342.95: 338(477)$ & УДК & 20 & Набір на клавіатурі \\
\hline $\begin{array}{l}\# 328:^{\wedge} \text { A12.00.07 "Адміністративне право } \\
\text { i процес; фінансове право; інформаційне } \\
\text { право"^N12.00.07 }\end{array}$ & $\begin{array}{l}\text { Примітки про дисертації: } \\
\text { назва та номер } \\
\text { спеціальності ВАК }\end{array}$ & 76 & Набір на клавіатурі \\
\hline $\begin{array}{l}\# 910:{ }^{\wedge} \mathrm{A} 0^{\wedge} \mathrm{B} 999999 \mathrm{~K}^{\wedge} \mathrm{DBPI} Д^{\wedge} \mathrm{E} 10.00^{\wedge} \mathrm{H} 999999 \\
\mathrm{~K}^{\wedge} \mathrm{U} 2019 / \mathrm{NNN}^{\wedge} \mathrm{YNNN}^{\wedge} \mathrm{C}\end{array}$ & $\begin{array}{l}\text { Відомості про } \\
\text { екземпляри }\end{array}$ & 6 & $\begin{array}{l}\text { Набір на клавіатурі } \\
\text { (заміна NNN) }\end{array}$ \\
\hline$\# 905:^{\wedge} \mathrm{B} 1^{\wedge} \mathrm{F} 1^{\wedge} \mathrm{H} 1^{\wedge} \mathrm{J} 1^{\wedge} 21$ & Службова інформація & 6 & \\
\hline$* * * * *$ & Кінець запису & 0 & \\
\hline \multicolumn{2}{|l|}{ Усього } & 314 & \\
\hline
\end{tabular}


Висновки. Розглянувши процес автоматизації створення бібліографічного опису авторефератів, зауважимо, що він має певні переваги та недоліки. Зокрема, висококваліфіковані та досвідчені каталогізатори ставлять під сумнів можливість економії часу, стверджуючи, що за допомогою наведеного методу 50 авторефератів можна опрацювати за дві-три години, тоді як віртуози своєї справи здатні зробити це швидше.

До переваг належать такі:

— автоматизація рутинної роботи зі створення запису автореферату;

- економія кадрового ресурсу, адже не потрібен фахівець вищої кваліфікації, який швидко й чітко опрацьовує такі документи;
- запропонований метод не втрачає актуальності за тотальної диджиталізації [2; 3], оскільки створення електронного запису значно прискорює пошук серед повних текстів. Якщо в майбутньому бібліотеки отримуватимуть цифрові версії документів, це дасть змогу спростити процеси автоматизованого створення бібліографічного запису завдяки тому, що такі ланки, як сканування та розпізнавання документів стануть зайвими.

Коли запис створено, слід скорегувати неточно розпізнані поля: назва, автор, колективний автор тощо, а також дані про номер акту NNN КСО (рис. 4) для всіх записів партії та інвентарний номер (999999) для кожного запису.

Список використаних джерел

1. Основні вимоги до дисертацій та авторефератів дисертацій // Бюлетень ВАК України. — 2007. — № 6. - С. 9-17 ; Бюлетень ВАК України. — 2009. — № 5. — С. 26-30 ; Бюлетень ВАК України. — 2011. — № 9-10. - С. 2-10. — Режим доступу: http://anu.edu.ua/uploads/aspirantura-17-18/19720.pdf. - Назва з екрана.

2. Слово року 2019. - Режим доступу: http://myslovo.com/?page_id=4634. - Назва з екрана.

3. Володимир Зеленський: Наша глобальна мета - побудувати країну з добре розвинутою цифровою економікою. Режим доступу: https://www.president.gov.ua/news/volodimir-zelenskij-nasha-globalna-meta-pobuduvati-krayinu-z-58593. Назва з екрана.

\section{Oleksandr Kuznetsov Automation of creation bibliographic description of dissertation abstracts}

The article deals with the optimization of the cataloging process of dissertation abstracts at the State Scientific and Technical Library (SSTL) of Ukraine. Automation of entering bibliographic descriptions of dissertation abstracts into the database is based on the fact that according to the current rules a bibliographic description of the publication is created from the title page. However, abstracts do not have a cover sheet, so the main information is taken from the cover. According to the rules for composing a thesis abstract, the title page is designed so that each paragraph contains certain bibliographic information.

The process of automating the creation of a bibliographic description of abstracts, in fact, involves the programmatic placement of indices of division in the text from the covers of these documents, which facilitates their further import into the relevant database.

The analyzed automated abstract introduction process was developed with the help of VBA software for Word and tested in the Scientific Research and Development Fund department of the SSTL.

Keywords: cataloging; abstracts; automation; bibliographic description; algorithm; coding

\section{References}

1. Osnovni vimogi do disertacij ta avtoreferativ disertacij (2019). Byuleten VAK Ukrayini, 2007, 6, pp. 9-17 ; Byuleten VAK Ukrayini, 2009, 5, pp. 26-30 ; Byuleten VAK Ukrayini, 2011, 9-10, pp. 2-10. Available at: http://anu.edu.ua/ uploads/aspirantura-17-18/19720.pdf.

2. Slovo roku 2019. (2019). Available at: http://myslovo.com/?page_id=4634.

3. Volodimir Zelenskij: Nasha globalna meta - pobuduvati krayinu z dobre rozvinutoyu cifrovoyu ekonomikoyu (2019). Available at: https://www.president.gov.ua/news/volodimir-zelenskij-nasha-globalna-meta-pobuduvati-krayinu-z-58593.

Надійшла до редакції 8 січня 2020 року

УДК 004:338.436](477)(045)

DOI: $10.36273 / 2076-9555.2020 .2(283) .37-42$

Оксана Капралюк,

кандидат сільськогосподарських наук, завідувач відділу науково-методичної роботи та наукового реферування Начіональної наукової сільськогосподарської бібліотеки НААН, e-mail: Oksanulichka@bigmir.net ORCID: https://orcid.org/0000-0002-2034-8958

\section{Система науково-інформаційного забезпечення агропромислового комплексу Украӥни}

У статті проаналізовано сучасний стан інформаційних ресурсів, сформованих на різних рівнях управління. Наведено характеристику національної системи науково-технічної інформачії (НTI) з питань сільського господарства. Зазначено, що ї̈ головними користувачами є вчені; товаровиробники; керівники, менеджери; висвітлено особливості забезпечення інформаційних потреб иъього сегмента. Зауважено, що серед галузевих інформаційних систем важливу роль у розвитку агропромислового комплексу країни (АПК) відіграють інформачійні системи: Міністерства розвитку економіки, торгівлі та сільського господарства України, Міністерства освіти і науки Украӥни, Національної академії аграрних наук України, 